\title{
THE ANALYSIS OF FORAGE QUALITY FOR ORGANIC MILK PRODUCTION IN FRUŠKA GORA REGION
}

\author{
GRDOVIĆ SVETLANA*, SAVIĆ MILA*, JOVANOVIĆ S*, POPOVIĆ-VRANJEŠ ANKA**, \\ PETRUJKIĆ $\mathrm{B}^{\star}$ and BOSANČIĆ $D^{\star \star *}$ \\ *University of Belgrade, Faculty of Veterinary Medicine, $R$ Serbia \\ **University of Novi Sad, Faculty of Agriculture, $R$ Serbia \\ ${ }^{* * *}$ Center for food quality research $L t d$, Belgrade, $R$ Serbia \\ (Received $7^{\text {th }}$ September 2009)
}

As a result of the growing demand for organic products, especially organic milk, the livestock organic production has increased. In this paper botanical and chemical composition of forage for organic diary cow production in Fruška Gora region were analysed. In the mixed hay samples, species from the Poaceae family were classified, according to their nutritive value into the first class. Dominant presence of Dactilys glomerata L. and Poa pratensis was revealed. Lucerne hay was predominantly composed only by one leguminous species Medicago sativa L. Basic nutritive components of mixed and Lucerne hay: crude moisture, crude ash, crude protein, crude fat, crude cellulose, calcium (Ca), magnesium (Mg) phosphorous $(P)$, copper (Cu), iron (Fe), manganese (Mn) and zinc (Zn) were determined. Determined levels of hazardous and noxious substances (mycotoxins, pesticides and heavy metals) in all hay samples were in the range according to regulations.

Botanical analysis has confirmed the presence of plants with high yield and of high nutritive value. Chemical analyses of hay samples originating from Fruška Gora has pointed out that the level of crude proteins, cellulose, fats, macro and trace elements can completely satisfy the requirements of animals in organic farming and therefore can present a solid base for further development of organic dairy farming.

Key words: forage, botanical composition, chemical composition, organic production

\section{INTRODUCTION}

During the past decade, the general attitude of the human population towards health, nutrition quality and environment has remarkably changed. As a result of the growing demand for organic products, especially organic milk, the livestock organic production has increased (Rosati, 2004; Von Borell, 2004; Sundrum, 2001). 
Council regulations (EC) No 2092/91 and 1804/99 describe in detail the allowed organic livestock management in Europe. Great emphasis is placed on welfare friendly feeding. Principles of organic livestock feeding require that ruminant diets should be based on organic feeds in the form of a balanced ration that provides requirents for high quality products rather than maximizing output. Organic standards require that forage must comprise at least $60 \%$ of the dietary dry matter intake of the organic dairy cow. Aiming for self-sufficiency, organic farming is characterized as a low external input agro-ecosystem. According to organic production standards, all feed should come from the farm itself, or at least should be produced within the region (IFOAM 2002, 2005; Hass et al. 2007).

Fruška Gora is a low mountain in the flatlands of the Pannonian Plain. The valleys of Fruška Gora are covered with meadows and grain fields spread over its slopes, while its higher parts, above 300 meters, are covered with dense deciduous forests. Geographic conditions, good climate and soil conditions of Fruška Gora region promote an intensive use of pastures and meadows. Vegetation of Fruška Gora is characterised by different types of meadow and pastures which are composed from numerous species. Four types of pastures and meadows can be distinguished: lowland meadows, highland meadows and pastures, swamp meadows and pastures of the river valleys (Butorac, 1991). Each of the mentioned types, is rich with the most significant species of meadowpasture grasses that are of importance in dairy cow nutrition.

In this paper, botanical and chemical composition of Lucerne and mixed hay samples originating from 8 localities of Fruška Gora region was investigated, as well as its self sufficiency for satisfying requirements for organic milk production.

Particular emphasis is laid on the amount of present toxic matters since they pose a threat to animal and human health (Horrigan et al., 2002).

\section{MATERIAL AND METHODS}

\section{Analyses of botanical composition}

Hay samples from Fruška Gora mountain region were taken in a period from August to September 2009. Eight samples each from mixed and Lucerne hay were analyzed. Hay was properly conserved, all parts of the plant were preserved which has enabled exact botanical analyses. Plants species were determined by floral determination key (Flora Srbije VIII, 1976; Javorka and Csapody, 1991). Determined species were sorted into classes according to their nutrient value. Based on organoleptic properties and chemical composition hay quality was determined, consecutively scored and classified according to Lenient (1969). Dactilys glomerata L. hay grown in our region gives average yearly yield of 10 to $15 \mathrm{t} / \mathrm{ha}$ and Poa pratensis L. 7-10 t/ha. Lucerne hay in Vojvodina yields yearly 8.2 to $8.4 \mathrm{t} /$ ha (Vučković et al,. 2002) .

\section{Analyses of chemical composition}

Hay samples $(n=16)$ were collected according to procedure AS-1064 (1993). Content of crude ash, crude protein, crude fat, crude cellulose and nitrogen free extract (NFE) was determined in relation to dry matter. 
Sample preparation for analyses was done on a procedure according to AOAC (1990). Determination of basic nutritive components was done according to the following procedures: crude moisture SRPS ISO 6496/2001; crude ash SRPS ISO 5984/2002; crude protein SRPS ISO 5983/2001; crude fat SRPS ISO $6492 / 2001$; and content of crude cellulose according to accredited laboratory method (DM1); while content of (NFE) was determined by calculation. Content of calcium (Ca) and magnesium (Mg) was determined by SRPS ISO 6869/2004 and phosphorous $(P)$ by spectrophotometry. Content of trace elements, copper $(\mathrm{Cu})$, iron (Fe), manganese (Mn) and zinc ( $\mathrm{Zn}$ ) was determined by atomic absorption spectrophotometry according to SRPS ISO 6869/2004.

Presence of aflatoxins $\left(B_{1}+G_{1}\right)$ was investigated by enzyme linked immune assay ELISA, IHM-03-007. Presence of mercury and arsenic was determined by hydride generated atomic absorption spectrophotometry (HGAAS, IHM-03-001); cadmium and plumb by graphite furnace atomic absorption spectrophotometry (GFAAS, IHM-03-001). Presence of organophosphate insecticides (hch, lindane, aldrine and dieldrine, heptachlor and heptachlor dioxide, DDT, endrine, endosulphane) was determined by gas chromatography according to procedure GC-ECD, IHM-03-002.

All mentioned procedures comply with the Rule Book for Feed Sampling and Analyses (SI. list SFRJ br. 15/87), as well as with Animal Feed Rule Book (SI. list SRJ br. 20/00 and 38/01).

A statistical analysis of samples was done by GraphPad Prism, descriptive statistical parameters were used (Xsr, SD and CV).

\section{RESULTS}

By botanical analyses in samples of the mixed, as well as in lucerne hay samples the presence of grass species of high nutritive value was determined. Species determined in the mixed hay samples, were classified, according to their nutritive value into first class. Presence of following species from Poaceae family was revealed: Dactilys glomerata L., Poa pratensis L., Alopecurus pratensis L., Lolium perenne L., Arrhenatherum elatius (L.) M.et Koch and Agropyrum repens (L.) P.B.. From Fabaceae family following species were present: Trifolium pratense L., Trifolium repens L. and Lotus corniculatus L. Determined dominant species in the mixed hay samples were Dactilys glomerata L. and Poa pratensis L.. Medical herbs, such as: Achillea millefolium L., Plantago media L., Teucrium chamaedrys $L$. and Taraxacum officinale Web. were also present. All mixed hay samples were with pleasing aroma, green colour and without notable presence of dust and smack and were classified into second class of hay (hay of good quality).

Lucerne hay was predominantly composed only by one leguminous species Medicago sativa L. Colour of Lucerne hay was greenish, with pleasing aroma and therefore classified into first class (hay of very good quality).

Chemical composition of hay samples is shown in Table 1. Presence of toxic maters (mycotoxins, pesticides and heavy metals) is shown in Table 2. 
Table 1. Chemical composition of hay samples

\begin{tabular}{|c|c|c|c|}
\hline \multicolumn{2}{|c|}{ Parameter } & \multirow{2}{*}{$\begin{array}{c}\text { Mixed hay }(n=8) \\
13.70 \pm 0.46\end{array}$} & \multirow{2}{*}{$\begin{array}{c}\text { Lucerne hay }(n=8) \\
13.01 \pm 0.57\end{array}$} \\
\hline Moisture & Xsr $\pm S D$ & & \\
\hline (\% DM) & CV \% & 3.37 & 4.38 \\
\hline \multirow{2}{*}{$\begin{array}{l}\text { Crude ash } \\
(\% D M)\end{array}$} & $X s r \pm S D$ & $7.69 \pm 0.84$ & $7.88 \pm 0.31$ \\
\hline & CV \% & 10.93 & 3.88 \\
\hline \multirow{2}{*}{$\begin{array}{l}\text { Crude protein } \\
(\% D M)\end{array}$} & $X s r \pm S D$ & $10.13 \pm 0.70$ & $16.32 \pm 0.48$ \\
\hline & CV \% & 6.94 & 2.92 \\
\hline \multirow{2}{*}{$\begin{array}{l}\text { Crude fat } \\
\text { (\% DM) }\end{array}$} & $X s r \pm S D$ & $1.04 \pm 0.13$ & $0.88 \pm 0.08$ \\
\hline & CV \% & 12.21 & 9.33 \\
\hline \multirow{2}{*}{$\begin{array}{l}\text { Crude cellulose } \\
\text { (\% DM) }\end{array}$} & $\mathrm{Xsr} \pm \mathrm{SD}$ & $33.96 \pm 3.72$ & $39.57 \pm 1.01$ \\
\hline & CV \% & 10.95 & 2.55 \\
\hline \multirow{2}{*}{$\begin{array}{c}\text { NFE } \\
(\% \text { DM) }\end{array}$} & $\mathrm{Xsr} \pm \mathrm{SD}$ & $33.05 \pm 2.27$ & $22.34 \pm 1.08$ \\
\hline & CV \% & 6.86 & 4.83 \\
\hline \multirow{2}{*}{$\begin{array}{l}\text { Calcium } \\
(\% \text { DM) }\end{array}$} & $\mathrm{Xsr} \pm \mathrm{SD}$ & $1.11 \pm 0.39$ & $2.79 \pm 0.19$ \\
\hline & CV \% & 34.90 & 6.98 \\
\hline \multirow{2}{*}{$\begin{array}{l}\text { Phosphorous } \\
\text { (\% DM) }\end{array}$} & $\mathrm{Xsr} \pm \mathrm{SD}$ & $0.38 \pm 0.09$ & $0.55 \pm 0.05$ \\
\hline & CV \% & 22.86 & 9.07 \\
\hline \multirow{2}{*}{$\begin{array}{l}\text { Magnesium } \\
\text { (\% DM) }\end{array}$} & $\mathrm{Xsr} \pm \mathrm{SD}$ & $0.21 \pm 0.04$ & $0.31 \pm 0.03$ \\
\hline & CV \% & 20.36 & 8.47 \\
\hline \multirow{2}{*}{$\begin{array}{c}\text { Iron } \\
(\mathrm{mg} / \mathrm{kg})\end{array}$} & $\mathrm{Xsr} \pm \mathrm{SD}$ & $358.4 \pm 81.11$ & $1279 \pm 175.7$ \\
\hline & CV \% & 22.63 & 13.74 \\
\hline \multirow{2}{*}{$\begin{array}{c}\text { Zinc } \\
(\mathrm{mg} / \mathrm{kg})\end{array}$} & $\mathrm{Xsr} \pm \mathrm{SD}$ & $17.63 \pm 1.00$ & $18.08 \pm 1.21$ \\
\hline & CV \% & 5.68 & 6.68 \\
\hline \multirow{2}{*}{$\begin{array}{l}\text { Manganese } \\
(\mathrm{mg} / \mathrm{kg})\end{array}$} & $\mathrm{Xsr} \pm \mathrm{SD}$ & $43.10 \pm 7.39$ & $87.26 \pm 5.90$ \\
\hline & CV \% & 17.14 & 6.76 \\
\hline \multirow{2}{*}{$\begin{array}{l}\text { Copper } \\
(m g / k g)\end{array}$} & $\mathrm{Xsr} \pm \mathrm{SD}$ & $8.52 \pm 0.78$ & $8.63 \pm 0.20$ \\
\hline & CV \% & 9.10 & 2.29 \\
\hline
\end{tabular}

* \% DM - percentage of dry matter

By analyses content of hazardous and noxious substances in samples of hay from Fruška Gora, determined level was in the range according to regulations (Rule book, 02/90). Therefore, all hay samples cultivated in this region can be regarded safe for use as animal feed. 
Table 2. Presence of toxic matters (mycotoxins, pesticides and heavy metals) in hay samples

\begin{tabular}{|c|c|c|c|}
\hline & $\begin{array}{l}\text { Mixed hay } \\
\quad(n=8)\end{array}$ & $\begin{array}{l}\text { Lucerne hay } \\
\qquad(n=8)\end{array}$ & $\begin{array}{l}\text { Method } \\
\text { deployed }\end{array}$ \\
\hline \multicolumn{4}{|l|}{ Mycotoxins } \\
\hline Aflatoxins (B1+G1) & $2.59 \pm 0.13 \mu \mathrm{g} / \mathrm{kg}$ & $2.7 \pm 0.09 \mu \mathrm{g} / \mathrm{kg}$ & ELISA, IHM-03-007 \\
\hline \multicolumn{4}{|l|}{ Metals and metalloids } \\
\hline Arsenic (As) & $0.10 \mathrm{mg} / \mathrm{kg}$ & $0.10 \mathrm{mg} / \mathrm{kg}$ & HGAAS, IHM-03-001 \\
\hline Mercury $(\mathrm{Hg})$ & $0.10 \mathrm{mg} / \mathrm{kg}$ & $0.10 \mathrm{mg} / \mathrm{kg}$ & HGAAS, IHM-03-001 \\
\hline Cadmium (Cd) & $0.05 \mathrm{mg} / \mathrm{kg}$ & $0.05 \mathrm{mg} / \mathrm{kg}$ & GFAAS, IHM-03-001 \\
\hline Leads $(\mathrm{Pb})$ & $0.20 \mathrm{mg} / \mathrm{kg}$ & $0.20 \mathrm{mg} / \mathrm{kg}$ & GFAAS, IHM-03-001 \\
\hline \multicolumn{4}{|l|}{ Organochlorine pesticides } \\
\hline $\begin{array}{l}\mathrm{HCH} \text { (isomers alpha, delta } \\
\text { \& beta) }\end{array}$ & $0.010 \mathrm{mg} / \mathrm{kg}$ & $0.010 \mathrm{mg} / \mathrm{kg}$ & GC-ECD, IHM-03-002 \\
\hline Lindane & $0.010 \mathrm{mg} / \mathrm{kg}$ & $0.010 \mathrm{mg} / \mathrm{kg}$ & GC-ECD, IHM-03-002 \\
\hline Aldrine \& dieldrine & $0.010 \mathrm{mg} / \mathrm{kg}$ & $0.010 \mathrm{mg} / \mathrm{kg}$ & GC-ECD, IHM-03-002 \\
\hline $\begin{array}{l}\text { Heptachlor \& } \\
\text { heptachlor-peroxides }\end{array}$ & $0.010 \mathrm{mg} / \mathrm{kg}$ & $0.010 \mathrm{mg} / \mathrm{kg}$ & GC-ECD, IHM-03-002 \\
\hline DDT \& derivates & $0.010 \mathrm{mg} / \mathrm{kg}$ & $0.010 \mathrm{mg} / \mathrm{kg}$ & GC-ECD, IHM-03-002 \\
\hline Endrine & $0.010 \mathrm{mg} / \mathrm{kg}$ & $0.010 \mathrm{mg} / \mathrm{kg}$ & GC-ECD, IHM-03-002 \\
\hline $\begin{array}{l}\text { Endosulphane (isomers } \\
\text { alpha, beta \& sulphate) }\end{array}$ & $0.010 \mathrm{mg} / \mathrm{kg}$ & $0.010 \mathrm{mg} / \mathrm{kg}$ & GC-ECD, IHM-03-002 \\
\hline
\end{tabular}

\section{DISCUSSION}

Sustainability of farming system under organic management may be increased by the introduction of Lucerne in crop rotation. Lucerne is a recognized as the most widely adapted agronomic crops, important and the cheapest source of protein rich forages of excellent amino acid composition and high digestibility, which is so valuable in economical animal husbandry. Beside that, this species is important for soil improving, especially as effective source of biological nitrogen fixation and it has important place in crop rotation. It is one of the few cultivated plants that can produce high levels of biomass with minimum inputs. It's a reason why Lucerne, besides an important role in conventional husbandry is getting a great role in sustainable agriculture and organic production (Annicchiarico et al., 2006).

Based on analyses of chemical and botanical composition samples of mixed hay investigated in this study were classified into second quality hay. Since two plant species were predominant (Dactilys glomerata L. and Poa pratensis L.) production of 8.5 to $10.5 \mathrm{t} / \mathrm{ha}$ could be expected. Calculated crude protein content 
of plants grown (according to nitrogen percentage) gives average yield of 861 to $1266 \mathrm{~kg}$ per ha.

Dairy cows with average milk yield of $5.000 \mathrm{~kg} \mathrm{milk} \mathrm{animal}^{-1}$ year $^{-1}$ in organic farming, have demands of $115 \mathrm{~kg}$ of crude nitrogen which equals $718.75 \mathrm{~kg}$ of crude protein (Lund, 2003).

Mixed hay samples cultivated on one ha in region of Fruška Gora can therefore provide nutrients for breeding of 1.20 to 1.76 dairy cows, per ha. Bakker and Heerdt (2005) have monitored forage quality on the grasslands in the Netherlands, during the period of 11 years after transition from conventional to organic farming. They have concluded that it remained sufficient for the production of $6000 \mathrm{~kg} \mathrm{milk} \mathrm{animal}^{-1}$ year $^{-1}$. The vegetation showed considerable changes during the study period. The sandy pastures initially featured a strong dominance of $L$. perenne, which however declined dramatically from $90 \%$ to $20 \%$ cover during the study period. At the end of the study period six grass species occurred with similar cover percentages, namely, Alopecurus pratensis, Dactylis glomerata, Elymus repens, $H$. lanatus, $L$. perenne and $P$. trivialis. These findings are in accordance to our findings since we have found that Dactylis glomerata and Poa pratensis were the dominant species. On the other hand Korevaar (1986) found that on extensively, unfertilized grazed grassland due to low nitrogen availability, finds hard to reach the forage quality to feed a cow with a production of $5000 \mathrm{~kg} \mathrm{milk}$ animal ${ }^{-1}$ year $^{-1}$ properly. Based on our findings pastures and meadows of Fruška Gora, present a solid base for organic dairy farming.

Measured crude protein content of Lucerne hay was $16.32 \%$ which gives 1338 to $1371 \mathrm{~kg}$ of crude protein per ha of Lucerne hay. This amount of proteins can therefore provide demands of 1.86 to 1.91 dairy cows with milk production of $5.000 \mathrm{~kg} \mathrm{milk}$ animal $^{-1}$ year $^{-1}$. This result is in compliance with the results of (Marković et al., 2007a and Đukić et al., 2007). The Lucerne hay is characterized by a high content of crude protein, well balanced with respect to amino acids. It is rich in vitamins, and various trace elements essential for normal growth and development of animals (Marković et al., 2007a). Lucerne is the basic component in the feeding program for dairy cattle, as well as for beef cattle, horses, sheep and other classes of livestock. Beside that, rapid recovery after cutting, longevity and tolerance to environmental stress is important for stabile yield during all periods of exploitation. Also, symbiotic N2 fixation in Lucerne eliminates the need for use of chemical $\mathrm{N}$ and adds a beneficial carryover effect in crop rotation.

In Serbia, Lucerne is the second most important forage crop after maize. It is grown on over 200000 ha in pure stand, which is about $4 \%$ of total agricultural area in Serbia (Đukić et al., 2007). Sustainable agriculture and organic production are an important part of research projects and agricultural development in Serbia, and the special role in those productions belongs to Lucerne. Lucerne is regarded as a highly nutritious animal feed and it is preferred to other forages in feeding ruminants. The demand arises because its primary nutritive values is based on rapid passage through the gastrointestinal tract, large amounts of soluble protein provided for rumen microorganisms for resyntesis of proteins, synthesis of $B$ vitamins and stimulation of cellulose digestion, vitamin $A, E$ and $K$ or their precursor contents all of which are vital protective nutrients when Lucerne forages 
are fed to dairy cattle. Lucerne has relatively large amounts of cell solutes and the lowest amount of cell walls in comparison with other forages (Tomić et al., 2001).

The Lucerne hay samples were characterized by higher Ca-contents $(2.79 \pm 0.19)$, compared to mixed hay samples $(1.11 \pm 0.39)$. The contents of $P$ were, however, similar to those of grasses. These finding are in accordance to the findings of Gruber et al. (1999). Content of trace elements in examined mixed and Lucerne hay samples did not differ significantly. Similar to these were the findings of Marković et al. (2007b).

The practical value of Lucerne is not restricted to its fodder qualities alone. It also performs other important economic and biological functions: it enriches the soil with nitrogen, is a good predecessor for many agricultural crops, serves as a desalinator crop, it's a good green-manure and nectar producing crop and reduces effect of water and wind erosion by binding the soil. Cultivation of Lucerne in crop rotation fields not only improves soil fertility, but also increases the yield of subsequent crops. All this traits make Lucerne essential in organic agriculture (Torricelli, 2006).

Organic farming concept is based on use of minimally $60 \%$ of roughage which originates from organically cultivated grasslands in the region of the farm. Production level of grasslands on Fruška Gora gives the possibility for breeding 1.20 to 1.91 dairy cows per ha of grassland, depending on hay type (mixed or Lucerne hay) and therefore can be a solid base for further development of organic dairy farming.

\section{ACKNOWLEDGEMENTS:}

This research was conducted within the project "Organisation of milk and dairy products production based on the principles of organic production and sustainable development" no. 20100, financed by the Ministry of Science and Technological Development of the Republic of Serbia.

Address for correspondence:

Dr Svetlana Grdović

Faculty of Veterinary Medicine

University of Belgrade

Bulevar oslobođenja 18,

11000 Belgrade, Serbia

E-mail: cecag@vet.bg.ac.rs

\section{REFERENCES}

1. Annicchiarico P, Pecetti L, De Rosa L, Piano E, 2006, Lucerne variety evaluation for organic farming in nothern Italy. Proceedings $26^{\text {th }}$ EUCARPIA Fodder Crops and Amenity Grasses Section Meeting, 65-71.

2. AOAC (Association of Official Analytical Chemists), 1990, Official Methods of Analysis of the Association of Official Analytical Chemists, Thirteenth Edition, Association of Official Analytical Chemists (publisher), Washington, DC 20044, USA, 1018.

3. AS-1064, 1993, Sampling Feed for Analysis.

4. Bakker JP, Heerdt ter GNJ, 2005, Organic grassland farming in the Netherlands: a case study of effects on vegetation dynamics, Basic Appl Ecol, 6, 205-14.

5. Butorac $B, 1991$, Neke biljke diferencijalnog karaktera za floru zapadnog dela Fruške gore, Zbornik radova PMF, Univerziteta u Novom Sadu. Serija za biologiju, 21, 5-14 [in Serbian]. 
6. DM1, Određivanje sadržaja celuloze - dokumentovana akreditovana metoda Laboratorije Katedre za ishranu i botaniku.

7. Đukić D, Lugić Z, Vasiljević S, Radović J, Katić S, Stojanović I, 2007, Domaće sorte višegodišnjih leguminoza - nastanak i kvantitativna svojstva, Zbornik radova, Institut za ratarstvo i povrtarstvo, Novi Sad, 44, 1, 7-20.

8. EC, 1991, Council Regulation (EEC) No 2092/91 of 24 June 1991 on organic production of agricultural products and indications referring thereto on agricultural products and foodstuffs, Offic Jour Europ Commun, L198 (22.7.91), 1-15.

9. EC, 1999, Council Regulation (EC) No 1804/1999 of 19 July 1999 supplementing Regulation (EEC) No. 2092/91 on organic crop production of agricultural products and indications referring thereto on agricultural products and foodstuffs to include livestock production, Offic $J$ Europ Commun, L222 (24.8.1999), 1-28.

10. Flora SR Srbije VIII, 1976, Srpska akademija nauka i umetnosti, Beograd.

11. Gruber L, Steinwidder A, Stefanon B, Steiner B, Steinwender R, 1999, Influence of grassland management in alpine regions and concentrate level on $\mathrm{N}$ excretion and milk yield of dairy cows, Livest Prod Sci, 61, 155-70.

12. Haas G, Deittert C, Köpke U, 2007, Impact of feeding pattern and feed purchase on area - and cow related dairy performance of organic farms, Livestock Sci, 106, 132-44.

13. Horrigan L, Lawrence RS, Walker $P$, 2002, How sustainable agriculture can address the environmental and human health harms of industrial agriculture, Environ Health Perspect, 110, 445-56.

14. IFOAM (International Federation of Organic Agriculture Movements), 2002, Norms for Organic Production and Processing-IFOAM, Basic Standards, IFOAM, Head office, Bonn, Germany.

15. IFOAM (International Federation of Organic Agriculture Movements), 2005, Norms for Organic Production and Processing-IFOAM, Basic Standards, IFOAM, Head office, Bonn, Germany.

16. Javorka S, Csapody V, 1991, Iconographia florae partis austro-orientalis europae centralis, Akademiai Kiado, Budapest.

17. Korevaar $H$, 1986, Produktie en voedingswaarde van gras bij gebruiks- en bemestingsbeperkingen voor natuurgebieden. Report 101, Proefstation voor de Rundveehouderij, Schapenhouderij en Paardenhouderij, Lelystad.

18. Leinkeit W (Ed.), 1969, Handbuch der Tierernährung, Zweiter Band: Leistungen and Ernährung. Verlag Paul Parey, Hamburg, Berlin, 1-52.

19. Lund V, Algers B, 2003, Research on animal health and welfare in organic farming-a literature review, Livest Prod Sci, 80, 1-2, 55-68.

20. Marković J, Ignjatović S, Radović J, Lugić Z, 2007b, Uticaj faze razvića na sadržaj makro i mikroelemenata u lucerki i crvenoj detelini, Zbornik radova, Institut za ratarstvo i povrtarstvo, Novi Sad, 44, 1, 401-6.

21. Marković J, Radović J, Lugić Z, Sokolović D, 2007, The effect of development stage on chemical composition of alfalfa leaf and stem, Biotechnology in Animal Husbandry, 23, 5-6, Book 2, 3838.

22. Marković J, Radović J, Lugić Z, Sokolović D, 2008, Nutritive value in leaves and stems of lucerne with advanced maturity and a comparison of methods for determination of lignin content, Proceedings of the $22^{\text {nd }}$ General Meeting of the European Grassland Federation, Upsala, Sweeden, 9-12 June, 480-2.

23. Pravilnik o kvalitetu i drugim zahtevima za hranu za životinje (SI. list SRJ br. 20/00 i 38/01).

24. Pravilnik o maksimalnim količinama štetnih materija i sastojaka u stočnoj hrani (SI. list SFRJ br. 02/90).

25. Pravilnik o metodama uzimanja uzoraka i metodama fizičkih, hemijskih i mikrobioloških analiza stočne hrane (SI. list SFRJ br. 15/87).

26. Rosati A, Aumaitre A, 2004, Organic dairy farming in Europe, Livest Prod Sci, 90, 41-51.

27. Sundrum A, 2001, Organic livestock farming - a critical review, Livest Prod Sci, 67, 207-15.

28. Tomić Z, Ignjatović S, Radović J, Sokolović D, 2001, Lignifikacija celuloze i mineralnih materija u travama, leguminozama i festololium hibridima, Biotechnol Anim Husban, 17, 5-6, 219-25. 
29. Torricelli R, 2006, Evaluation of lucerne varieties for organic agriculture, Proceedings 26th EUCARPIA Fodder Crops and Amenity Grasses Section Meeting, 141-4.

30. von Borell E, Sorensen JT, 2004, Organic livestock production in Europe: aims, rules and trends with special emphasis on animal health and welfare, Livest Prod Sci, 90, 3-9.

31. Vučković S, Simić A, Jakovljević M, Petrović R, Mladenović G, Marina Vučković, 2002, Forage yield and quality of perennial ryegrass as affected by different rates of nitrogen fertilizer under calcareous soils in north-western Yugoslavia, Grassland Scince in Europe, 7, 486-7.

\title{
ISPITIVANJE KVALITETA SENA SA FRUŠKE GORE U ORGANSKOJ PROIZVODNJI MLEKA
}

\author{
GRDOVIĆ SVETLANA, SAVIĆ MILA, JOVANOVIĆ S, POPOVIĆ-VRANJEŠ ANKA, \\ PETRUJKIĆ B i BOSANČIĆ D
}

\section{SADRŽAJ}

Kao rezultat povećanja tržišnih potreba za organskim proizvodima, naročito za mlekom, došlo je do intenziviranja organskog stočarstva u Srbiji. U ovom radu je ispitivan botanički i hemijski sastav dve vrste sena iz regiona Fruške Gore koja se koriste u organskoj proizvodnji mleka. U uzorcima mešanog sena, prisutne vrste iz familije Poaceae su na osnovu hranljive vrednosti klasifikovane u prvu klasu livadsko-pašnjačkih trava. Utvrđeno je prisustvo Dactilys glomerata L. i Poa pratensis L. Seno lucerke je u najvećem delu bilo sastavljeno od jedne vrste, Medicago sativa L. Određivan je sadržaj osnovnih hranljivih materija u mešovitom senu i senu lucerke: sirova vlaga, pepeo, proteini, mast i celuloza. Pored njih određivan je i sadržaj $\mathrm{Ca}, \mathrm{Mg}, \mathrm{P}, \mathrm{Cu}, \mathrm{Fe}, \mathrm{Mn}$ i Zn. Utvrđeni nivo štetnih materija (mikotoksini, pesticidi i teški metali) bio je u propisanim granicama. Botaničkom analizom je utvrđeno da su u uzorcima bile zastupljene biljke koje su zadovoljavajuće hranljive vrednosti i daju velike prinose. Hemijskom analizom utvrđeni nivo proteina, celuloze, masti, makro i mikroelemenata može u potpunosti da zadovolji potrebe mlečnih krava u organskoj proizvodnji i predstavlja dobru osnovu za dalji razvoj organskog stočarstva. 